\title{
7 ECOWAS and triangular cooperation for peacebuilding in West Africa
}

\author{
Challenges and prospects from the Liberian \\ and Sierra Leonean experiences
}

\author{
Kehinde Olusola Olayode
}

\section{Introduction}

The expansion of the role of the Economic Community of West African States (ECOWAS) from being an organisation primarily focused on economic integration to include conflict resolution and peacebuilding activities in the 1990s exemplified the changing security environment across Africa and the convergence of development and security issues in the post-Cold War era. The outbreak of civil wars in Liberia and Sierra Leone, and unconstitutional changes in power in other West African countries, and accompanying humanitarian crises necessitated a review of ECOWAS's foundational statutes to accommodate peacekeeping and peacebuilding interventions. ECOWAS-led peacebuilding in Liberia and Sierra Leone involved responses to multiple complex emergencies arising from the collapse of central administration and its attendant consequences. These included the collapse of various administrative organs of the state and institutions; refugee crises and internal displacement-related issues; resettlement and post-war rehabilitation and economic reconstruction. Others include rehabilitation of infrastructure, democratic transitions, and elections; reconciliation; disarmament and arms destruction; security sector reforms; and justice and restitution (truth and reconciliation). Given resource limitations and capacity deficiencies, ECOWAS-led peace initiatives were supported by multilateral agencies, South-South partners, and Western powers in a triangular pattern of cooperation for peacebuilding in West Africa.

South-South cooperation as a development framework has a long history. It is based on the building of shared histories and mutual economic, political, and cultural interests. The pivotal role of several emerging powers in the global South have created a compelling context for mainstreaming South-South cooperation framework peacebuilding efforts in developing countries. It seeks to shift the paradigm of development cooperation away from dominant asymmetrical donor-recipient, North-South, neo-colonial relationships, towards global "partnerships" with an emphasis on national and community ownership, equity, sustainability, inclusiveness, regional solutions, cost-effectiveness, and affordability. These principles are relevant to peacebuilding and resonate with the core principles of South-South cooperation (Sesay, Olayode, and Omotosho, 2013, 97). The 
recognition of the immense potential of South-South development cooperation in the context of shared interests in sustainable peacebuilding is a recent development (United Nations, 2009).

Triangular cooperation refers to a version of South-South cooperation involving collaboration between Southern aid providers and Northern donors for the benefit of a third Southern recipient country. It can find expression either in trilateral, regional, or multilateral arrangements. Incorporating triangular cooperation into peacebuilding and post-conflict reconstruction resonates with the United Nations (UN) agenda for peacebuilding, which emphasises the importance of cooperation between the UN and regional organisations for preventive diplomacy within their respective areas of competence.

This chapter examines the prospects and challenges of triangular cooperation in peacebuilding projects, using post-conflict Liberia and Sierra Leone as case studies. It addresses the following questions: (1) What are the political and economic constraints that have hampered ECOWAS initiatives in peacebuilding in West Africa? (2) What are the lessons that can be learned from the Liberian and Sierra Leonean cases in relation to ECOWAS's experience with triangular cooperation for building sustainable peace in West Africa? and (3) Can triangular cooperation (multilateral and bilateral) be instituted as a permanent framework for peacebuilding in West Africa?

\section{Conceptual framework}

Triangular cooperation involves Southern-driven partnerships between two or more developing countries, supported by developed countries or multilateral organisations to implement development programmes and projects. It has been described by the Organisation for Economic Co-operation and Development (OECD) as "partnerships between Development Assistance Committee (DAC) donors and Pivotal Countries (providers of South-South Cooperation) to implement development cooperation projects in beneficiary countries" (OECD, 2009). ${ }^{1}$ Thus, "triangular cooperation is South-South cooperation with the added dimension of Northern support to the southern partner assisting other developing countries" (ECA, 2011, 1). It, however, can also be undertaken by Southern partners only as pivotal countries (ECOSOC, 2008; OECD, 2009).

Pivotal countries are Southern countries that have capacity and experience in promoting South-South cooperation and are thus well-placed to promote technical cooperation among developing countries by "sharing their capacities and experiences with other developing countries in their regions or in other regions" (ECA, 2011, 2). In Liberia and Sierra Leone, various versions of triangular cooperation manifested in trilateral, regional, and multilateral arrangements. For example, the India, Brazil, and South Africa (IBSA) funds could be seen as a trilateral arrangement, in support of ECOWAS peacebuilding initiatives in the two countries. In addition, the participation of several UN agencies and other multilateral institutions in post-conflict reconstruction and peacebuilding is another example of a multilateral triangular cooperation. 
Peacebuilding as conceived by the UN Secretary-General's Report in the 1992 Agenda for Peace involves "action to identify and support structures, which will tend to strengthen and solidify peace in order to avoid a relapse into conflict" (UN, 1992, 21). This definition was further elaborated upon by two subsequent UN documents: the 2000 Report of the Panel on United Nations Peace Operations (known as the Brahimi Report), and the UN Secretary-General's Policy Committee in the 2007 Report.

According to Ismail $(2008,13)$, some essential features of post-conflict peacebuilding include:

Disarmament, guarding and destruction of weapons, repatriating and resettling refugees, advising and retraining security actors, monitoring elections and protection of human rights, reforming and strengthening government institutions, police and judicial systems, [and] reforms and economic development.

The concept of peacebuilding is also intrinsically related to state-building in the context of collapse of state institutions during the Liberian and Sierra Leonean civil wars. Peacebuilding in West Africa usually involves multiple complex emergencies associated with the collapse of central administration (failed state phenomenon) and its attendant consequences. As noted earlier, the cases of Liberia and Sierra Leone contributed to the ascendancy of politico-security issues in ECOWAS's agenda of economic integration as a strategy of regional development.

\section{Wars and attendant complex emergencies}

The interconnectedness of conflicts in West Africa should be in the context of strong historical and cultural ties between the peoples of the sub-region. This is further reinforced by artificial boundary demarcations that have aided unrestricted movements across borders. The porosity of borders has enabled dissident elements from one country to cross over into neighbouring ones to wage insurgencies. The ECOWAS peacekeeping intervention started as a regional response to the Liberian civil war in late 1989, which later spilled over into Sierra Leone in 1991, triggering a brutal ten-year armed conflict (Obi, 2009). The first Liberian civil war commenced in December 1989 and lasted until 1997. The war started when Charles Taylor's National Patriotic Front of Liberia (NPFL) crossed the border from Côte d'Ivoire into Liberia with a small band of Libya-trained rebels, seeking to overthrow the repressive regime of Samuel Doe. The insurgency initially started in Nimba county and gradually gained ground due to the support that Taylor obtained from neighbouring countries and many dissident groups that opposed Doe's brutal regime. The fighting later escalated into civil war, with different factions struggling for the control of central power.

The civil war in Sierra Leone was arguably a direct fall-out of the Liberian civil war. The Revolutionary United Front (RUF) was led by the aging Foday Sankoh, who had received training with Taylor in Libya and fought on the side 
of NPFL in Liberia. Taylor found a willing ally in Sankoh in his desire to explore the lucrative illegal diamond trade in Sierra Leone to fund his insurgency. Taylor also claimed that by allowing its territory to be used as an operational base for the ECOWAS Cease-fire Monitoring Group (ECOMOG), Sierra Leone had indirectly declared war against the NPFL and thus became a legitimate target for the NPFL. The RUF commenced its attack from the eastern and southern Sierra Leone border areas with Liberia in March 1991, claiming a desire to overthrow President Joseph Saidu Momoh because of corruption and repressive leadership. The RUF campaigns in Sierra Leone were characterised by wanton brutality against civilians, destruction of property, and savage plunder of mineral resources. The collapse of central state authorities was accompanied by massive dislocation, widespread human rights abuses, bloodshed, outbreaks of epidemics, looting, and arms trafficking. The Report of the ECOWAS Standing Mediation Committee of 1990, where a decision was taken to dispatch the ECOMOG peacekeeping force to Liberia, highlighted the attendant security emergencies triggered by state collapse in Liberia (ECOWAS 1990, 3-4). The ECOWAS Standing Mediation Committee on 7 August 1990 established ECOMOG in Liberia "to halt the wanton destruction of human life and property and massive damage being caused the armed conflict to the stability and survival of the entire Liberian nation" (ECOWAS, 1990, 3).

Referring to the connections between conflicts and regional security in West Africa, an analyst for an international humanitarian organisation noted:

The arc of instability in West Africa is linked together. The violence is interwoven. War in Liberia begat war in Sierra Leone, which in turn begat attacks in Guinea and prolonged the civil war in Cote d'Ivoire. The recognised borders do not mean anything to many of the hardcore combatants. When a country finally achieves a peace treaty, the guys who make a living through the barrel of their guns seep across the border to the next country.

(Drumtra, 2003, 1)

The Liberian civil war, which roughly lasted for 14 years, can be typically divided into two phases, the first spanning 1989-1997 and the second 1999-2003 (Shilue and Fagen, 2014, 1). The civil wars in Liberia and Sierra Leone provided vivid examples of state collapse and attendant humanitarian crises, which justified the creation of the ECOWAS Conflict Prevention Mechanism. ECOWAS peacekeeping interventions began with the Liberian civil war in 1989 and continued in Sierra Leone in 1997; Guinea-Bissau in 1998; the second Liberian civil war in 1999; Côte d'Ivoire in 2002; the second Côte d'Ivoire civil war in 2011; Mali in 2012; and the second Guinea-Bissau crisis in 2012 (Ukeje and Olayode, 2015, 9).

\section{ECOWAS's initiatives for peacebuilding in Liberia and Sierra Leone}

In the context of an unprecedented humanitarian crisis and global powers' disengagement from African conflicts after the Cold War, the Liberian crisis was 
a turning point in ECOWAS's agenda of promoting economic development and regional integration, to taking responsibility for collective security and conflict management in the sub-region.

Following a protracted and unproductive dialogue with various faction leaders in Liberia, the ECOWAS Standing Mediation Committee in August 1990, took the bold step of establishing and deploying ECOMOG amid bitter opposition from then rebel leader Taylor and some West African leaders. ECOMOG was charged with both mediating between the warring factions and neutralising them through forceful disarmament, if necessary. It also had peace enforcement and peacekeeping objectives. The deployment of ECOMOG to Liberia faced many difficulties. The deployment was opposed by Taylor, who was the dominant rebel leader in Liberia. Personal interests and ideological differences between Francophone and Anglophone members of ECOWAS made the task of peace restoration difficult in Liberia. In addition, procedural and operational disagreement among ECOWAS members also frustrated the deployment of troops by ECOMOG to Liberia.

ECOMOG's military intervention in Sierra Leone was predominantly undertaken by Nigeria-led troops to restore the democratically elected government of Ahmad Tejan Kabbah, who was deposed in a military coup led by Major Johnny Paul Koroma on 25 May 1997. The coup was undertaken by a segment of the Sierra Leone Army that supported the RUF. Koroma established the Armed Forces Revolutionary Council and made Sankoh vice-chairman. After the restoration of Kabbah, under the Lomé Agreement, a power-sharing arrangement saw Sankoh emerge as the vice president and head of the Commission for the Management of Strategic Mineral Resources, National Reconstruction, and Development (Ismail, 2015). With the withdrawal of Nigerian troops from the ECOWAS peacekeeping force in Sierra Leone and relentless attacks by the RUF, the UN Security Council eventually established the UN Mission in Sierra Leone (UNAMSIL).

ECOWAS multilateral peacekeeping initiatives have been repeatedly criticised for being ineffective and for exacerbating the conflicts in Liberia and Sierra Leone because of inadequate resources, lack of broad political support, and limited knowledge of the conflict terrains (Howe, 1997, 168-169; Obi, 2009, 8-9; Ismail, 2015, 4-5). However, Draman and Carmen (2003, 17) have argued that ECOMOG's operations, though largely ineffective, "succeeded in containing the Liberian and Sierra Leonean conflicts in the short term and also prevented the situation from degenerating into genocide as witnessed in Rwanda in 1994."

Although initially conceived as a peacekeeping force, ECOMOG's actual mission "bordered on peace-making and peace-enforcement, which was a clear departure from its original mandate" (Whiteman, 1990, 28). Resource constraints also limited the effectiveness of ECOMOG operations. While provision was made for the deployment of over 12,000 troops, inadequate funds and lack of military materials and equipment only permitted mobilisation of a limited number of soldiers, which was grossly inadequate for an effective peacekeeping operation.

As stated earlier, ECOWAS's multilateral peacekeeping operations, though imperfect, taking into consideration the Liberian and Sierra Leonean experiences, were the first to be undertaken by an African sub-regional organisation. 
The intervention also reflected an African attempt to resolve an African conflict through regional cooperation. Thus, without previous experience to draw from, the modest achievements recorded in Liberia were significant. While ECOWAS indeed faced enormous challenges in peace intervention, its military and diplomatic engagements paved the way for subsequent international efforts that finally ended devastating conflicts in the Mano River Basin region between 1990 and 2003. Although critics may point to its limited effectiveness, the ECOMOG intervention could be seen as "as a harbinger of potential African solutions to some of Africa's pressing security problems" (Pitts, 1999, 1).

On the humanitarian front, ECOMOG was successful in reducing casualties and wanton destruction and provided safe passage for trapped civilians to be evacuated out of troublesome war zones. In addition, by securing the port and airport essential relief supplies were obtained for thousands of displaced civilians in dire need. In the context of state collapse and absence of administrative functions, ECOMOG in effect functioned as a police and defence force within its occupational zone (Scott, 1998, 19).

\section{Triangular cooperation for peacebuilding}

Faced with resource and capacity limitations, ECOWAS's multilateral peace initiatives paved the way for the subsequent intervention of UN and Western powers in a triangular cooperation framework for peacebuilding. In Liberia and Sierra Leone, ECOMOG co-deployed peacekeepers with UN observer missions, while ECOWAS missions in Liberia (ECOMIL) and Côte d'Ivoire (UNOCI) provided rapid deployment forces that were transformed into UN peacekeepers. Despite problems of coordination and logistics, and differences in mandate, the cooperation between the UN and ECOWAS allowed each organisation to maximise its comparative advantage while working together to resolve the conflicts. Lessons learned from these missions provided a blueprint for how the UN and regional organisations could work together (Kabia, 2011, 2-4).

While the notion of "African solutions to African problems" is a highly commendable aspiration, the capacity for sustainability required in post-conflict peacebuilding is currently weak within ECOWAS because of inadequate funding, poor logistics, ideological differences, and weak capacity, among other things. A consequence of some of these deficiencies was that Nigeria pulled out from direct ECOMOG peacekeeping operations due to the heavy financial cost incurred in the Liberian and Sierra Leonean operations. This paved the way for the United Kingdom, the UN, France, and the African Union (AU) to become more substantially involved in post-conflict reconstruction in Sierra Leone and Liberia through triangular cooperation arrangement. A triangular South-South cooperation was also adopted in Côte d'Ivoire, Guinea-Bissau, and Mali, with France playing a leading role, supported by the AU and ECOWAS. The challenges of sustaining peacekeeping operations faced by ECOWAS also led to the "rehatting" of ECOMOG forces as UN peacekeepers in Liberia, Sierra Leone, and Côte d'Ivoire. 
In Liberia and Sierra Leone, the checklist of tasks involved in peacebuilding and post-conflict reconstruction included

deployment of peacekeepers; undertaking disarmament, demobilisation, and reintegration of ex-fighters; judicial and security sector reform; economic reconstruction reforms to facilitate development aid and assistance packages; and elections.

(ICG, 2004, 1)

In undertaking these various tasks, a combination of regional, trilateral, and multilateral arrangements involving various state and non-state actors were involved in both Liberia and Sierra Leone.

The United Nations Mission in Liberia (UNMIL) was established by the UN Security Council Resolution 1509 in 2003 to assist the National Transitional Government of Liberia to establish the rule of law and undertake post-conflict reconstruction and peacebuilding. The international donor community provided considerable financial support to the Liberian peacebuilding process and post-conflict recovery efforts. A National Commission for Disarmament Demobilisation, Reintegration, and Rehabilitation was established to implement the Accra Comprehensive Peace Agreement signed by the various warring factions in August 2003. Disarmament, Demobilisation, Reintegration, and Rehabilitation (DDRR) activities in Liberia were strictly donor-driven, with disarmament and demobilisation undertaken by UNMIL while reintegration and rehabilitation were coordinated by the UN Development Programme (UNDP) as mandated by international partners through a memorandum of understanding. The Japanese government provided financial support for the overall disarmament component of the DDRR programme. Security reforms of the Liberia National Police were undertaken with help from UN Police and support from the United States (US), Belgium, India, Ghana, Norway, the European Union (EU), Ghana, Egypt, and various UN agencies. For the armed forces, the United States (US) through the private security firm DynCorp led the process of restructuring of the Armed Forces of Liberia. Other countries that supported this process were Ghana, China, Nigeria, the United Kingdom (UK), and France.

Another major international stakeholder involved in DDRR activities in Liberia was UNICEF, which focused on disarming, demobilising, and reintegrating former child-soldiers. A partnership was forged between UNDP and UNICEF for the national rehabilitation of children. The Carter Centre in the US was invited by President Charles Taylor of Liberia to undertake justice sector reform. The World Bank was also actively involved in post-war reconstruction and infrastructure development

In Sierra Leone, post-conflict reconstruction has ranged from security sector reform to economic reform. Bilateral and multilateral support was received from donor governments and organisations. The World Bank supported the Poverty Reduction Strategy, while the British government through the Ministry of Defence and DFID assisted in the security sector and civil service reforms. 
Other international organisations that supported the post-war reconstruction in Liberia were Oxfam, World Vision, and the Norwegian Refugee Council, which have set up country offices; the National Endowment for Democracy, based in the US; and the Westminster Foundation for Democracy, based in the UK. The latter two have given financial support to local organisations for work on human rights and governance issues.

In Sierra Leone, the UK assumed responsibility for security sector reform through the British Military Advisory and Training Team, while India, Brazil, and South Africa undertook a project on leadership development and institutional capacity building for human development and poverty reduction. The project was undertaken under the framework of triangular cooperation involving India, Brazil, and South Africa in partnership with UNDP. The World Bank has played a significant role in post-war peacebuilding, notably through its focus on the plight of internally displaced peoples (IDPs), and the provision of basic infrastructural faculties and social amenities destroyed in the civil war.

ECOWAS also benefited from triangular cooperation in peacebuilding through training activities for the military forces of its member states to improve operational capacities for peacekeeping. The US and France were actively involved in this capacity-building project on the protection of refugees, command and control, and negotiation techniques, among others (Ismail, 2015, 14). For example, the US established the African Crisis Response Initiative for the purpose of training and enhancing the capacity and efficiency of West African militaries in diverse humanitarian and peacekeeping activities (Howe, 2001, 19).

\section{Challenges of triangular cooperation for peacebuilding}

The challenges experienced in triangular cooperation in peacebuilding operations in West Africa are like those of other modalities of development cooperation. Some of these challenges include lack of proper coordination among different actors operating in the field, which sometimes results in duplication of efforts and conflicts. Other challenges identified were high implementation costs due to excess reliance on using experts from the global North; the existence of distinct procedures and institutions from different countries; lack of agreement on harmonised common standards and procedures for measurement and evaluation; weak local content due to problems of adaptation; and unclear division of roles and responsibilities (OECD, 2009, 4-5).

The logic behind triangulation in development cooperation involving developing countries is the belief that Southern developing partners are better placed, and possess relevant experience, to respond to the needs of beneficiary countries that are developing themselves. It is expected that these Southern development partners should take the lead in implementing development projects, with the necessary support from Northern donors, where required. However, the peacebuilding operations in Liberia and Sierra Leone did not follow the "normal" structure of South-South triangular relations, but displayed characteristics of mainstream donor-dependent, North-South relations. The key actors involved in 
implementation of post-conflict reconstruction and peacebuilding projects were from the North, while Southern partners were relegated to background and supportive roles.

The strategic structure and direction of the peacebuilding processes in Liberia and Sierra Leone were fundamentally flawed and hindered the effective operation of South-South partnerships. The trend displayed in the two cases was an informal arrangement whereby ECOWAS/ECOMOG provided the human resources for peacekeeping but were side-lined in critical components of the peacebuilding decision-making efforts. Critical issues relating to entry and exit strategies, coordination, finance, and timing were decided by Western institutions and actors. However, during conflicts, regional and sub-regional entities bring long-standing relationships, depth of understanding and determination, and often a willingness to respond to complex humanitarian emergencies.

The bitter rivalries between ECOMOG and the UN over leadership positions in UNAMSIL, which resulted in a verbal war between Nigeria and UNAMSIL, exemplified the disagreement over ownership. India contributed the largest contingent to UNAMSIL and thus assumed the overall command. However, ECOWAS asserted that the Indian commander, being unfamiliar with West African conditions, should be replaced by a commander from West Africa. The ECOWAS resolution even suggested that the multinational peacekeeping force should be replaced by a regional West African peacekeeping force. The tension generated by this appointment forced India to announce its withdrawal from peacekeeping responsibilities in UNAMSIL.

Another contentious issue was the ownership, control, and implementation of peacebuilding processes. National governments are best positioned to respond effectively to the non-military elements of peacebuilding (Haze, 2007). In a postconflict context, long-term interventions linked to capacity-building initiatives require national ownership. Also, an inclusive reintegration and rehabilitation process may be difficult to achieve in the absence of national ownership. The likelihood of exclusion may lead critical actors in the war to withdraw from the peacebuilding processes to take up arms against the government.

However, in most cases post-conflict states are characterised by a weakened institutional base, thus making it difficult for them to undertake peacebuilding activities without external support. Again, regional arrangements sometimes suffer from crises of trust and legitimacy, especially when pivotal actors in the arrangements are parties to the conflicts. They also bring their own interests, some of which carry potential risks to managing conflict impartially. This was the situation in Liberia and Sierra Leone that hindered ECOWAS in the peacebuilding and conflict resolution processes. External support is also needed to forge inclusive peacebuilding arrangements in a war-torn environment to prevent the isolation of critical opponents by incumbent governments that may want to use peacebuilding processes to shore up their political positions.

Funding is a critical constraint in the operation of regional cooperation for peacebuilding in West Africa. The modest successes recorded by ECOWAS in peacekeeping operations through ECOMOG were largely due to the 
financial, logistical, and diplomatic support of Nigeria. As one of the founders of ECOWAS, Nigeria provided politico-economic leadership to the organisation in an effort to develop a collective regional peace and security mechanism in West Africa (Francis, 2006, 147). Nigeria has provided about 60 percent of the ECOWAS budget; there is no doubt that multilateral peacebuilding under the auspices of ECOWAS is intimately linked to Nigeria's active cooperation and contributions. This was evidently demonstrated in Liberia and Sierra Leone, where Nigeria was the major provider of military and other resources for peacekeeping operations. At the peak of the Liberian and Sierra Leonean crises in the 1990s, Nigeria provided over 70 percent of ECOMOG's military and civilian personnel, as well as logistical support (Hamman and Omojuwa, 2013, 4-5). Many ECOWAS member states cannot make significant financial contributions to peace missions due to domestic economic and development challenges. Funding is a major challenge for the AU, ECOWAS, and other African sub-regional organisations. Given the enormous resources committed to peacekeeping operations in Liberia and Sierra Leone through ECOMOG, domestic pressures and internal security challenges compelled Nigeria from 1999 to shift focus from leading military peacekeeping operations to conflict prevention initiatives.

\section{Prospects for triangular cooperation for peacebuilding in West Africa}

The prospects for triangular cooperation for peacebuilding are very promising in West Africa, given the institutional reforms undertaken by ECOWAS. Dictatorial governments are now the exception rather than the rule in the sub-region due to ECOWAS's zero-tolerance for unconstitutional changes in government. There is also increasing involvement and engagement with civil society organisations in the areas of conflict resolution, post-conflict reconstruction, and peacebuilding (see Chapter 5). ECOWAS has evolved - in capacity and sophistication in the areas of regional security and peacebuilding. Several legal and institutional frameworks have been established to address the challenges of human security, governance, and sustainable development (see Chapter 4). However, to consolidate these achievements, West African leaders must continue to deepen democratisation. Civil society actors must also remain vigilant and act as watchdogs to expose corruption, dictatorial leaders, and political excesses. Sustainable economic growth and institutional reforms are also needed to diversify national economies, catalyse economic growth, and improve quality of life, which will prevent relapses into resource-starved and poverty-induced conflicts.

Furthermore, the valuable experience of the different UN agencies, especially the UNDP, in integrating South-South cooperation into their different activities could be an important asset for the UN Secretariat, especially the agencies responsible for peacekeeping and peacebuilding operations - the Department of Political Affairs, Department of Peacekeeping Operations, and the Peacebuilding Support Office. They can utilise existing institutional structures to also incorporate 
triangular and South-South cooperation into conflict prevention and peace operations in Africa.

The new development environment as conceptualised in the Sustainable Development Goals (SDGs) agenda prioritised the nexus between security and development; for example, SDG 10, which focuses on reduction of inequality, and SDG 16 on peace, justice, and strong institutions resonate well with ECOWAS's agenda of West African development. The new SDGs and the broader sustainability agenda go much further than the Millennium Development Goals in "addressing the root causes of poverty and conflicts, and the universal need for development that works for all people" (Olayode, 2015, 8). The SDG framework has underscored the need for wider application of developmentally focused South-South cooperation across the peace and security pillar of the UN's work.

In contemporary global peacebuilding strategies, regional and sub-regional arrangements have become prominent elements. The UN Agenda for Peace, the AU's Africa Peace and Security Architecture, and ECOWAS's peace and security mechanisms have all highlighted the significance of regional initiatives in preventing conflict and in peacebuilding. The UN's regional partnerships in Africa must be strengthened by creating effective mechanisms for effective partnership.

\section{Conclusion and recommendations}

South-South cooperation, with its emphasis on demand-driven, context-specific, long-term partnerships among equals, and involving the sharing of relevant expertise and experiences between developing countries, has shown its potential to become a catalyst for successful peacebuilding efforts.

While regional and sub-regional organisations like ECOWAS may not have the required resources to undertake post-conflict reconstruction singlehandedly, Western multilateral agencies also lack adequate knowledge and the necessary expertise to undertake peacebuilding alone. Triangular cooperation involving partnerships between ECOWAS and multilateral organisations is thus required to achieve the desired results in peacebuilding. For the partnership to be effective, a clear definition of roles and capacity-building should be agreed on to enhance the ability of the partnering countries both at regional and sub-regional levels. The multilateral agencies involved in triangular cooperation should therefore focus more on building local capacities rather than simply acting as "delivering agencies" (Ajayi, 2008, 5). This would enhance local ownership and promote sustainable human security.

Contemporary security threats and challenges, especially those relating to Islamist terrorism across the Sahel-Sahara belt and in the Gulf of Guinea, require collaborative efforts from member states in those regions, ECOWAS, the Intergovernmental Authority on Development, and the AU. Apart from regional initiatives, international assistance is needed for logistics, surveillance, training, funding, and technical support.

To conclude, for South-South and triangular cooperation to become a potent force in peacebuilding, recipient or beneficiary states in the developing world 
should take ownership of, and raise their own, resources, and actively participate in the process. They should also translate and adapt programmes to suit local realities. Similarly, South-South cooperation partners and DAC donor countries must also harmonise and coordinate their activities and strategies with beneficiary countries by dividing and allocating responsibilities based on their areas of expertise (OECD, 2009).

\section{Note}

1 Examples of Pivotal countries are China, India, South Africa, Malaysia, Thailand, Brazil, Nigeria, and Egypt.

\section{References}

Ajayi, T. (2008). The UN, the AU and ECOWAS - A triangle for peace and security in West Africa? (Briefing Paper No.11). New York: Friedrich Ebert Stiftung.

Draman, R., and Carmen, M. (2003). Managing chaos in the West African sub-region: Assessing the role of ECOMOG in Liberia. Journal of Military and Strategic Studies, (Fall), 7-8, 1-31.

Drumtra, J. (2003). West Africa's refugee crisis spills across many borders (Migration Policy Institute Feature Series). Washington: Migration Policy Institute.

ECA. (2011). South-South and triangular cooperation: Implications for Southern African countries. Addis-Ababa: Economic Commission for Africa.

ECOSOC. (2008). Trends in South-South and triangular development cooperation: Background study for the development cooperation forum. New York: United Nations Economic and Social Council.

ECOWAS. (1990). Final communique, First session of ECOWAS standing meditation committee. Banjul: ECOWAS.

Francis, D. (2006). Uniting Africa: Building regional peace and security systems. London: Ashgate Publishing Ltd.

Hamman, S., and Omojuwa, K. (2013). The role of Nigeria in peacekeeping operations, 1960 to 2013. Mediterranean Journal of Social Science, 4(16), 1-17.

Haze, J. (2007). Can peacekeepers be peacebuilders? International Peacekeeping 14(3), 323-338.

Howe, H. (1997). Lessons of Liberia: ECOMOG and regional peacekeeping. International Security, 21(3), 168-169.

Howe, H. (2001). Ambiguous order: Military forces in African states. Boulder: Lynne Rienner.

ICG. (2004, December 8). Liberia and Sierra Leone: Rebuilding failed states. Africa Report, 87. International Crisis Group.

Ismail, O. (2008). The dynamics of post-conflict reconstruction and peace building in West Africa. Discussion Paper 41, Nordiska Afrikainstitute, Uppsala.

Ismail, O. (2015). Towards a community of practice: ECOWAS and peace and security policy communities in West Africa. African Peace-Building Network Paper, 3, 3-16. New York: Social Science Research Council.

Kabia, J. (2011). Regional approaches to peacebuilding: The ECOWAS peace and security architecture. Paper presented at the BISA-Africa and International Studies ESRC seminar series: African Agency in International Politics African Agency in Peace, Conflict and Intervention at the University of Birmingham, April 7. 


\section{Kehinde Olusola Olayode}

Obi, C. (2009). Economic community of West African states on the ground: Comparing peacekeeping in Liberia, Sierra Leone, Guinea Bissau, and Cote d'Ivoire. African Security, 2(2-3), 119-135.

OECD. (2009). Triangular cooperation and aid effectiveness - Can triangular cooperation make aid more effective? OECD Policy Dialogue on Development Cooperation. Mexico City, September 28-29.

Olayode, K.O. (2015). Rethinking development beyond the MDGs: Africa and the challenges of governance in the post-2015 development agenda. Paper presented at the Institute of Development Studies 50th Anniversary. Kenya: Institute of Development Studies, University of Nairobi.

Pitts, M. (1999). Sub-regional solutions for African conflicts: The ECOMOG experiment. Journal of International Conflict Studies, 19(1), 1-4.

Scott, C. (1998). Liberia: A nation displaced. In R. Cohen and F. Deng (Eds.), The forsaken people: Case studies of the internally displaced (pp.107-120). Washington: Brookings Institution.

Sesay, A., Olayode, K., and Omotosho, M. (2013). Africa and South-South cooperation: Opportunities and challenges. In J. Dargin (Ed.), The rise of the global South (pp. 95123). Singapore: World Scientific Publisher.

Shilue, S., and Fagen, P. (2014). Liberia: Links between peace building, conflict prevention and durable solutions to displacement. Washington: Brookings Institution.

Ukeje, C., and Olayode, K. (2015). South-South and regional cooperation for peace building in West Africa. Paper presented at the Workshop on South-South Cooperation for Post Conflict Reconstruction \& Development in Africa, Wits School of Governance, November.

UN. (1992). An agenda for peace (A/47/277-S/24111). New York: United Nations. Retrieved on July 11, 2016 from http://www.un.org/Docs/SG/agpeace.html.

UN. (2009). Promotion of South-South cooperation for development: A thirty-year perspective. Report of the secretary general (A/64/504). New York: United Nations.

Whiteman, K. (1990). Towards peace in Liberia. West Africa, November 26-December 2 , 27-28. 